\title{
CARTA AOS LOUCOS: UMA NARRATIVA ÉPICA MODERNA
}

Moema de Castro e Silva Olival*

É preciso que o homem se passe, com armas e bagagens, para o lado do homem.

ANDRÉ BRETON

RESUMO

Carta aos loucos - romance de Carlos Nejar - é uma narrativa alegórica em que o autor, a partir da tradição da narrativa clássica de Homero, e valendo-se do recurso parodístico, instaura nova épica, assentada não no relato do acontecido, mas no questionamento, revelando a consciência crítica pós-moderna. Neste ensaio, procura-se relevar os meios pelos quais o narrador ousa novos paradigmas literários, recriando a mitologia clássica, em torno do binômio Tempo versus Palavra, e mostrar como, enriquecido com a convivência dinâmica da prosa e da poesia, o romance é a apologia do Verbo, tese que encontra reforço em ficcionistas contemporâneos.

Palavras-Chave: Binômio palavra versus tempo, épica moderna, prosa poética, literatura brasileira.

Uma narrativa alegórica, alicerçada em propósitos restauradores e inovadores, é como se apresenta Carta aos loucos, romance de Carlos Nejar, lançado pela Record em 1998.

Terceira obra em prosa do conhecido poeta, sua temática vai da tradição narrativa clássica de Homero para os questionamentos existenciais da contemporaneidade. Enfoca a travessia do homem pelo labirinto

* Doutora em Letras Clássicas e Vernáculas pela USP. Professora titular aposentada da Faculdade de Letras da UFG. 
da vida, travessia paradoxal, uma vez que tecida pela força mítica do Tempo que nos entretém mas que, também, nos tritura. E será o Verbo a força capaz de domá-lo, de subjugá-lo.

Deixa em suspense, na sua técnica labiríntica, uma evidência: a de ousar novos paradigmas literários para o gênero em questão.

As obras anteriores em prosa de Carlos Nejar foram Um certo Jacques Netan (1991) e O túnel perfeito (1994), este último considerado pelo Jornal do Brasil um dos dez melhores romances do ano, segundo dados incluídos na publicação. Nestas obras, já se esboçavam as dimensões humanísticas do autor.

Em Carta aos loucos, desde o início, instala-se o traço parodístico. Substituindo os heróis da tradicional alegoria mítica de Teseu, perseguindo e matando o Minotauro, temos agora o Teseu moderno, a Palavra, que se imporá ao Minotauro-tempo.

A palavra era. A palavra matava o tempo, o que matava. (CL p. 76) ${ }^{1}$

Este pensamento-núcleo da célula temática do romance Carta aos loucos, cujo potencial foi conscientizado e cultivado nos textos de filófosos-escritores modernos - Proust, Sartre, Heidegger - encontra reforço em ficcionistas contemporâneos, apontando para uma reincidência significativa de época, como se pode ver nas palavras de José Saramago, afixadas em painel, no grande Salão dos Espelhos, em Estocolmo, na Suécia, onde esteve para receber o Nobel de Literatura de 1988, como se vê a seguir:

Morre-se por não ter dito a palavra. Morre-se por não tê-lo feito; é por isso que se morre, e, não, por doença.

Temos, aqui, a saga desta luta implacável, levantando os meneios e a resistência de cada um dos opositores, testemunhados por uma voz plural - voz coral - de tantos personagens que se encarregarão de arregimentar a referida proposta temática da narrativa. 
Se, a partir do romantismo, já se prenunciava a destruição do preceito clássico da distinção entre os gêneros, descortinando possibilidades mais livres para a arte de narrar, o romance atual - restaurando a memória histórica da narrativa homérica, como matriz do gênero épico - se enriqueceu com a convivência dinâmica da prosa e da poesia.

Carta aos loucos se consagra, assim, como texto de grande poeticidade.

Nos entremeios da perseguição Teseu-Minotauro (palavra-tempo) como obstáculos naturais da caminhada, esboçados em linguagem poética, desfilam os questionamentos, as indagações, as lembranças dos "fogos extintos das paixões”, estimulados pelas dúvidas e pela procura, em que se envolvem perseguidos, perseguidores e testemunhas.

Segundo Antônio Carlos Secchin, a "narrativa arma-se nos entremeios das referidas indagações”.

E se o romance é uma ponte de "pensamento a pensamento", se a ponte se faz de "palavras", busca-se, nas possíveis soluções de fiar a trama do viver, a dialética persuasiva do pensamento, que, segundo Alexandre Mendez afirma na orelha de Carta aos loucos, está “a nos apontar o rio da memória em que o realismo mágico busca desembocar".

A interação vida-tempo-memória transpira de Assombro, “aldeiamulher”, símbolo da raça, da vida, do germinar dos sonhos.

E o escriba Israel Rolando, voz narradora quase mítica, no seu timbre sagrado de oráculo, busca sintonizar o anseio básico desta narrativa épica moderna "em cartas de uma aparente loucura que é sabedoria”.

Nomeio o que me falta? Nomeio de novo todas as coisas. E tenho um patrimônio de palavras. A semente de Deus é a diferença. Risco fósforos na sua pequena caixa, risco a memória. Chamo de Assombro o povoado. E assim designo o tempo. Dar nome é viver junto. (p. 15) 
Assiste-se, na seqüência dos depoimentos e indagações, o fortalecer da força do "Verbo", a única capaz de subjugar o Tempo.

Não escrevo: risco fósforos, risco a memória como um fósforo na sua pequena caixa.

E cada palavra tem sua memória. Riscar palavras é acender a memória.

E não posso riscar uma memória, em vez de outra. Nem uma palavra por outra.

(...)

Não escrevo: risco as imagens no tempo. (p. 16)

No serial mágico em que se sucedem as personagens e suas vozes - rapsódia a simbolizar a voz das massas no correr dos tempos destacaremos alguns dos depoimentos mais esclarecedores quanto ao embate que alimenta esta narrativa, embate travado entre Tempo e Palavra.

Em favor da força verbal no designar a vida, em suas infindáveis representações, vamos partir, juntamente com Israel Rolando, da afirmação de Assombro (sua mulher): "A vida toma o rumo das coisas" (p. 19).

E, como ingrediente fundamental da vida, busca-se, com Israel, situar o sonho que a dimensiona e a seqüência de vidas, cujo relato se segue, sempre na mira de suas perspectivas.
As imagens se aprofundam mais que os corpos.
(...)
E a minha humanidade ou desumanidade queima nos objetos, quando os sonhos também queimam (...)
Sonhei que Artêncio era um pássaro. E não era ele, nem seu corpo. Era a alma pousada no paraíso. E descobri que o sonho e o texto são esféricos, porque em círculo o pássaro voava. (p. 21)

A linguagem de Carta aos loucos tece uma grande alegoria a envolver as propostas do romance. E a figura do círculo é um dos pilares 
metafóricos mais freqüentes, numa simbolização do critério da perfeição e do plano mítico. Vejamos alguns exemplos:

Ora, o que se designa existe. E se o grego Arquimedes religou matemática e espelho, chegando ao ponto de incendiar, com o sol, navios, reteço o círculo para prender, nesta contínua jaula, o tempo. Ou tento abarcá-lo nos reflexos especulares, para que seja dominado como Teseu matou o Minotauro.

Parar o tempo? Huxley, escritor e cientista, também afirmava que ele devia parar. E se foi e o tempo continua. (p. 24)

O espelho, no corpo ou no rosto, não há de ser juiz, sendo cúmplice. A palavra, sim, sozinha ou unida ao círculo. Apontará onde o tempo dispara. (p. 25)

Sabemos, segundo Cortázar (1974, p. 79), que o romance contemporâneo "de compromisso com o imanente humano", em que se enquadra Carta aos loucos, procura a resposta para o porquê e o para quê do mundo dos homens; no do século passado, perguntava-se "gnosiologicamente" pelo como do referido mundo, enquanto no romance da antiguidade clássica este mundo era apenas narrado, sendo os homens guiados pelos acontecimentos.

Neste romance, Carlos Nejar busca o tom narrativo do oráculo, comum ao mítico e ao sagrado, em que o tempo se dilui in memoriam, para sintonizá-lo nos parâmetros modernos em que este Tempo e o Homem que o interroga são questionados nos seus limites e na sua ação.

Busca Nejar, então, a narrativa clássica, mas não a repete; renovaa, recria-a dialeticamente, circunscrevendo a angústia do homem, a sua atitude de tensão existencial, de interrogação de nosso tempo, condicionando sua linguagem às perspectivas de sua proposta. Daí a interação prosa-poesia (em Homero, épico, o romance não correspondia, em forma de expressão, aos versos brancos?) a demarcar os limites do humano, as suas potencialidades nos terrenos do amor e do sonho. E isto porque, ainda segundo Cortázar (1974, p. 66), 
a poesia implica a mais profunda penetração no ser de que é capaz o homem.(...) Centra seu foco nas suas dimensões profundas. (...) mas, para conhecer-se e conhecer, ele precisa do romance.

Portanto, ainda para ele, o romance retrata a

posse do homem como pessoa, do homem vivendo e sentindo-se viver. (CORTÁZAR, 1974, p. 67)

E o romance, sendo ação, e a poesia, sendo penetração, nada mais dinâmico do que a reunião destes gêneros que, no imbricar-se, poderão nos trazer a medida dialética do ser estudado, dimensionandolhe as angústias, a consciência, o particular tempo e sua manifestação.

$\mathrm{O}$ alto teor desta poeticidade se revela nas imagens que carregam o tom do sagrado e do mítico, a pairar no contínuo das ações. Encarregase, pois, o romance, de nos trazer inúmeras tomadas da caminhada existencial de tantas personagens e de expô-las ao leitor:

Vi o rosto de Aércio, o violinista, no jornal: uma das cordas não era do violino. Mas de sua alma. Como se corda portátil fosse. Só tocava com ela (...) Voltou ao povoado, velho e glorioso. Retornou à infância, à deserta casa, onde vivera com seus pais. Até a alma romper-lhe a corda. (p. 42)

Sempre percucientes são os trechos que demarcam as etapas do embate Tempo versus Palavra, como os que se seguem na voz de Israel Rolando, o escriba:

O prefeito daquela comunidade baixou um estranho decreto determinando que os mais idosos se afastassem e fossem expirar noutra região distante. E eles se recusaram a abandoná-la, sustentando que o decreto deveria exilar o tempo e, não, os homens. (p. 30)

Ou, então, aqueles em que se insiste no poder da palavra: 
Podemos ver o mundo de um navio, ou de um barril, através de seus buracos. Assim pensavam Platão, Rabelais e mais não refiro por lhaneza. Eu vejo o mundo através de minhas palavras. (p. 44)

No terceiro capítulo, o narrador instala um discurso político, parodístico, a dessacralizar, num extraordinário processo de carnavalização, o regime político que governa o país, seu presidente, sua fala, sua moeda visionária.

Neste capítulo, a personagem Sândalo Acabe - o astuto - (reparese no simbolismo do nome próprio) e seu estranho séquito, os Gabirus e os ratos, traduzem, em imagem carnavalizada, o governante "incensado" mas alienado e sua entourage de roedores. E centra o infortúnio maior na ausência da autenticidade do processo de comunicação:

Isolados, desconhecem a palavra e a palavra os desconhece. (p. 61)

Sempre idealista, a voz narradora propala a salvação pela palavra, como podemos ver nos exemplos a seguir:

A revelação solucionadora estava com a palavra do pacifista Orlando: os gabirus são seres humanos. Devemos ajudá-los a superar os ratos que estão neles. Se os acostumarmos a existir como gente, ou ensinarmos a eles o método de melhor alimentarse, com a límpida palavra que designa as novas coisas, ultrapassarão a condição gabiruana. (p. 67)

E tínhamos que riscar fósforos na mente de cada um deles, com a palavra. Magicamente reiterada. E mostrar o amor oculto no clarão. (p.68)

Refere-se, de modo intenso, às cartas de Novalis, o pastor dos versos, cuja voz incendiará as páginas, com suas calorosas e poéticas lições:

A poesia não esgota os sonhos; o amor, sim, esgota o esquecimento. (p. 87) 
No sexto capítulo, trata-se, de modo mais percuciente, do desvelamento do título do romance, como se vê no trecho selecionado a seguir:

Não seria a loucura a única forma de relacionamento com o universo?

A loucura é a sensatez do tempo. (p. 89)

O oitavo capítulo é a apologia do amor e releva o impacto das palavras que o vivenciam:

Cada coisa é revelada no amor. E o amor, em cada coisa. (p. 107)

A voz narradora tenta descortinar as faces prismáticas da palavra a serviço deste sopro renovador:

A palavra aciona a potência do silêncio. (p. 107)

Através de seu cão Tabor, Israel Rolando, o narrador, tenta desvelar as forças destruidoras do redemoinho - metáfora de um espaço concentrado e dinâmico de afetos e emoções - espaço em turbilhão, quando não devidamente canalizados por gestos e palavras.

Não seria (o redemoinho) conseqüência de um verso? (p. 108)

Fala, então de Tabor, e de sua cura pelo amor atento, através do "elixir" da palavra:

O elixir que miraculou o cão talvez possa, sorvendo-o, miracular cada vez mais a infância dos meus sonhos. (p. 108)

E conclui, penetrando na gênese do amor e do sonho:

O amor possui sentidos, não razão.

A palavra era maior que o sonho. (p. 118) 
No nono capítulo, o escriba Israel Rolando antecipa astutamente, profeticamente - se pensarmos no grande affair atual relativo à área jurídica, que produz as manchetes prediletas da imprensa em nossos dias - reflexões sagazes, maquiavélicas. Mostra, outra vez, sua voz política, ao tentar afinar a interpretação geral de leis e a face atualizada destas interpretações. Sai com preciosidades, como:

O excesso de leis resulta no excesso de fendas por onde os transgressores escapam. (p. 116)

$\mathrm{Ou}$, tratando carnavalescamente do funcionamento da justiça em Assombro, aldeia-mulher - matriz mítica e parodística da vida -, preocupa-se em tipificar os invasores extraterrestres na lei, quem sabe, numa referência visionária de um futuro não muito distante. Assim, relatando a denúncia de um agricultor que "propôs queixa-crime contra os extraterrestres, por terem assustado sua criação de porcos, especialmente, a das fêmeas, que deixaram de comer e procriar”, dá chance a espirituosas reflexões, sobretudo do juizado recém-implantado na aldeia e que,

ao tentar fundar a justiça do terceiro milênio, não esperava iniciar com denúncias contra Ets. (p. 118)

Entre suas atitudes premonitórias, destaca-se a do advento do matriarcado, fato que atribui, não ao acaso, mas à obstinação, competência e dedicado esforço das mulheres. Aliás, é preciso salientar o que parece ser a face primordial deste livro: o romance da virada do século. Com ele, Carlos Nejar marcará seu tempo na literatura contemporânea, lançando novo paradigma na área do romance.

No décimo capítulo denominado o "Livro do caminho", a alegoria se impregna das metáforas e referências simbólicas ao "círculo" (imagem da perfeição divina, conforme Platão). 
E o círculo é por mim riscado nesta página, e dentro escrevo Assombro. E entre o povoado e a mulher amada, digo imagens, digo, digo. E não sei, não sei mais morrer. (p. 141)

Plácido predicava por imagens. (p. 143)

A visão mágica da ressurreição do rio que circunda a aldeia Assombro, cuja seca revolucionou o ânimo de seus habitantes, ressurreição provocada por Plácido, é expressa mediante texto elaborado em recriação parodística sobre as palavras de Cristo a Lázaro. Nessa visão, o rio passou a chamar-se Orozal, isto é, Lázaro, quando lido em espelho, o que ratifica o peso da palavra.

Os sonhos só prevalecem na palavra. (p. 141)

Outra referência alegórica, reafirmando o poder da palavra, ocorre com a cena da luta dos cães Tabor e Jack, em que só a palavra fê-los estancar.

Foi quando disse a palavra e eles estancaram o assalto. Pararam no ar. Imóveis. (p. 145)

Também seria bom nos lembrarmos de que no simbolismo dos nomes Tabor (de Thabor, montanha calcárea de Israel, que dominava o lago Tiberíades, e de onde Cristo, falando com o Pai, tomou a palavra e a levou à multidão) e Jack (nome padrão em um grande país da civilização moderna, indicativo de povo) pode estar a sugestão do entendimento de diálogo entre as civilizações, entre os povos, entre as culturas. Tudo pela palavra. Processo metonímico como operador semântico do texto. Tabor, pela fonte do Verbo; Jack, pela multidão, pelo povo. O conquistador e o conquistado.

E me lembrei que Livro do Caminho, que meditamos com Martinho, Plácido e outros, adverte por um profeta: 'O leão e a ovelha pastarão juntos’. (p. 146) 
No décimo primeiro capítulo, intitulado "O maravilhoso não precisa de óculos”, o discurso alegórico assume as dimensões das falas míticas e proféticas. Refere-se ao diálogo entre Lino, as formigas e as cigarras, enaltecendo as condições de catequizador de Lino, sua capacidade de convencer pelas palavras. Lino, leitor de Pórfio, em "As catacumbas da História”, discípulo das sábias experiências de vida retratadas na obra, lembra-se de um pensamento que o impressionara: de que as formigas seguem, instintivamente, o preceito maquiavélico de que a paz pode ser um estágio perigoso, e, por isso, conhecendo os estratagemas, não serão usadas fora do carreiro: "Preparam-se, num corpo ileso, para o verão, sabendo que a paz é constante guerra”.

O discurso alegórico preenche os requisitos da fábula, num lance didático de visão moderna das experiências da vida. Assim, pela fala de Oriondo, sabe-se que Lino conseguira introduzir, entre cigarras e formigas, “convincente troca”, fazendo com que até as cigarras ficassem operosas. E, tudo, “pela cantiga de bom amor” (p. 161).

Tentou, entre elas, projetos de humanização: ensinar-lhes o alfabeto humano, carnavalizando a distância que separa homens e insetos:

Era a curiosidade dos insetos sobre os pobres seres terrestres, de quem não compreendiam o desespero, ou o desígnio mortífero. E aprendiam depressa. (p. 161)

Algumas vezes, em Carta aos loucos, a linguagem é mimética, fragmentada, refletindo, na expressão, seu conteúdo. Ao retratar a idéia de castração, por exemplo, também ela, sugestivamente, se castra:

Roda, girava o céu. Morreu no meio da palavra. No meio da. Um grito. A roda sempre tece uma armadilha. (p. 167)

Das discussões entre os sábios filósofos Lino, Agostinho e Oriondo, disseminam-se amplos debates sobre a essência do amor, do tempo, da compreensão ou da necessidade de apreender a linguagem nas suas 
tentativas de aprisionar o tempo, de rastrear a extensão da palavra, a única arma capaz de detê-lo e de fornecer a extensão do amor:

Não há suspeita mais incontroversa que a do amor. Todos sabem e ninguém necessita falar. (...) O tempo é uma forma de amor. (p. 179)

No livro dos espelhos, matéria do décimo segundo capítulo, que trata de Virgílio ou vigília (veja-se o jogo de palavras), acompanhamos as façanhas do aedo Virgílio - o que fazia os vocábulos cantarem - e de sua mãe Magia.

A alegoria se entretece de uma linguagem altamente metafórica e simbólica, buscando delinear o mito das origens da vida. Vejamos sobre o nascimento de Virgílio:

E como o hábito exigia que fosse plantada uma muda de choupo onde era parida uma criança, assim foi, e o ramo enterrado cresceu, igual ao loureiro do materno sonho, pois os sonhos, as árvores e os homens se originam desta esfera circular da terra, em que as gerações são enxames de abelhas. (p. 183)

Delineia-se, deste modo, o sincretismo da figura do poeta e a do cultor da palavra. Outro exemplo:

Quando Virgílio transitava pela rua, ouvia-se: 'É o poeta’. Como se apenas ele carregasse uma safira ou chama por muitos desejada. Só se apaga a palavra com a palavra. Será viável extingui-la? (p. 186)

Sobre a noção da essencialidade do tempo, e da escritura, eis como se delineia a questão para o poeta épico:

E o tempo, para ele, não tinha antes, nem depois. Tinha palavra. (p. 187)

Escrever é voar. E deixar plumosas, rugentes as palavras. (p. 186) 
Prosseguindo na trajetória final, vitoriosa, decisiva da palavra nos impactos existenciais, Pórfio - outro depoente da aldeia - sentenciou:

As confusões se curam com o silêncio. As efusões com a palavra. (p. 195)

E, assim, vão se experimentando as sendas que se abrem à compreensão das "pupilas revoantes” da linguagem. E Assombro é a aldeia-núcleo dos profetas do Verbo. Vejamos a atitude de outro de seus filósofos:

E Perci ia ajustando, com a palavra, desafortunados, deprimidos, neuróticos de guerra ou penúria, intoxicados de amor, desejo ou desespero. (p. 195)

Ao tratar sobre os sonhos do espelho, o escriba-narrador, Israel Rolando, ao ler o Livro do caminho, reinterpreta a profecia de Ezequiel:

Farei de ti uma penha descalvada, e virás a ser enxugadora de redes. Se essa profecia era dirigida à ilha Descalvada, com suas rochas, a cinco quilômetros de Assombro, nada sei, salvo que a penha é o próprio coração do homem. (p. 196)

Na ilha Descalvada se abrigam todos os heróis que ilustraram a narrativa alegórica e épica de Israel Rolando, cuja voz deixa transparecer, como autor implícito, a do poeta e pensador Carlos Nejar. Desfilam, pois, ante nossos olhos, vultos como Parmênides, Oriondo, Lino, Virgílio, Novalis, Orlando, Pórfio, e outros, cujos nomes e cujas vozes, relembrando o berço da civilização clássica da humanidade, realizam, nos seus pronunciamentos filosófico-poéticos, o sincretismo dos dois mundos: antiguidade e contemporaneidade, configurando, na articulação da trama, nova estrutura narrativa. Eis como a ilha se apresenta:

Era um éden de aves, corais e espumas. Espelho, onde Assombro se fixava. E, se dentro de cada espelho há sonhos, quantos esta ilha guardará? (p. 197) 
Segue-se um diálogo de Oriondo com o Oceano; a linguagem metafórica torna-se hermética, enfrentando-se dimensões várias:

Era o peso da leveza ou a leveza do peso: não importava, era. As coisas manam de estarem continuando. Aberta foi a nascente com jorros do céu. (p. 199)

E depois, transcendendo o papel do impacto do reconhecimento da presença da alma, volta-se à fonte do princípio vital:

Eterna é a alma, e o princípio só descansa na palavra. (p. 199)

No décimo terceiro e último capítulo, intitulado "De como o tempo morre. Arco-íris”, o núcleo do pensamento concentra-se no sistema de signos: a língua. E a poesia faz seu decreto, numa belíssima intertextualização do conhecido verso de Fernando Pessoa - "A língua é a minha pátria” -, e temos a renovadora e criativa paródia a indicar a postura contemporânea, lema dos escritores e poetas da atualidade:

A língua não é minha pátria, é minha descoberta. (p. 201)

O narrador, aqui, se refere aos matizes que as palavras assumem em novos contextos às possibilidades latentes destas palavras, aos seus desdobramentos pelos recursos intertextuais e da metalinguagem, reafirmando o potencial dinâmico do idioma e, assim, o actante princípio da renovação, numa postura de fé. Fé no poder da palavra, fé no alcance da linguagem.

As referências a personagens homônimas da tradição clássica e da contemporaneidade, como Diógenes, o padeiro, e Diógenes, o grego, ensejam contrastes de reflexões que giram em torno das realidades díspares no tempo, ou até muitas vezes iguais na mesmice das carências.

Presencia-se, na alternância dos tempos, também o questionamento dos conceitos, sobretudo no campo da medicina: médicos, saúde, tratamentos etc. Cita, por exemplo, Voltaire, a respeito desse tema, 
quando, cético e intrigante, Voltaire afirmava o que hoje, por vezes, ainda se presencia:

Os médicos inoculam drogas que não conhecem, em corpos que conhecem menos ainda. (p. 204)

E, aí, Israel Rolando, o nosso escriba, acrescenta:

Nem Voltaire, nem os médicos, sabem que a droga, antes referida, é o tempo. (p. 204)

A esta reflexão, Oriondo acrescenta:

E como o veneno da cobra engendra a sua cura, só o tempo é antídoto do tempo. O que fazia perecer, reanimava. Pois a morte retém, escondido no bojo, o germe de uma incontrolável vida. (p. 205)

Israel Rolando, o escriba de Assombro, termina a sua narrativa, relacionando mito, tempo e palavra. Diz ele:

O mito não existiria sem a invenção do tempo, e o tempo, sem a invenção do mito. Este, engatinha naquele, como um menino rechonchudo e esperto. A invenção do tempo é a invenção da morte. Que ele exista sem ela; cessando ou esquecendo. (p. 212)

A insistente recorrência à tradição grega, através dos nomes próprios, e o ritmo da linguagem recriando a imagem do oráculo reafirmam o intuito de rastrear a narrativa clássica, na busca do sagrado, do poético, do épico, revestindo de grandeza o texto redimensionado na marca do alegórico. A novidade é que Nejar busca instaurar uma nova épica, assentada não no relato do acontecido mas no seu questionamento, a marca do pós-moderno.

A grandeza acima mencionada poderá ser rastreada sempre, como vemos ao examinar um nódulo temático, exposto de forma grandiosa na 
voz de Martim, no décimo capítulo, sob o título: "Carta aos loucos de Deus”:

Não escrevo aos frios ou mornos de ânimo, ou aos filhos de cartesiana lógica. Escrevo aos albatrozes ou loucos de Deus. (p. 141)

Eis, pois, um romance, cuja trama foi elaborada nas teias do maravilhoso, e que expõe lances que são núcleo de irradiação de novas diretrizes semânticas, de cunho indagador e reflexivo perante os mistérios da vida e que se erigem em propostas de reflexão.

Quanto ao estilo, a escrita equilibra prosa e poesia, incrustrados no metafórico e simbólico, num continuum de alegoria, recurso que leva a leitura a outros níveis de decodificação. Imagens e ritmos se sucedem, numa extraordinária destreza de operações seletivas e combinatórias.

Carta aos loucos é prova evidente do credo que o autor-narrador professa: o do culto da palavra e de seu impacto sobre o Homem. Assim, evidente se torna a sua proposta, ainda que recoberta pelo alegórico; ou seja, o desvelamento se dá pelas ironias, paródias; às falsidades embutidas nos discursos convencionais, nas instituições, pelas alusões nos costumes e governos, e, sobretudo, no desamor que os reveste. Vergasta o tempo que os recobre e oficializa. E acena para a busca da palavra plena, autêntica, a que ressuscita e que dinamiza a vida, mais facilmente encontrada nos campos da poesia e do amor e a única arma capaz de vencer as limitações temporais.

Assim, Carlos Nejar, o poeta, autor de quase uma vintena de livros de poesia, muitas reunidas em antologias, como Os melhores poemas de Carlos Nejar (1998), com prefácio e seleção de Léo Gilson Ribeiro, consagra-se, agora, com Carta aos loucos, como o escritor-filófoso, a abrir trilhas nos campos da literatura da virada do século. As obras com estas características estabelecem enfoques prioritários no trato literário da contingência humana, sempre em busca de sua auto-realização, e se 
projetam no campo temático reflexivo e questionador e na estrutura carnavalizada, transfigurada de sua linguagem. Obras que instalam, reinauguram ou reforçam tendências.

Martim Heidegger, em Ser e tempo (1998), parece dar o diagnóstico certo em que se enquadra Carta aos loucos, quando afirma:

São os tempos de grande perigo em que aparecem os filósofos. Então, quando a roda rola com sempre mais rapidez, eles e a arte tomam o lugar dos mitos em extinção. Mas projetam-se muito à frente, pois só muito devagar a atenção dos contemporâneos para eles se volta. Um povo consciente de seus perigos gera um gênio.

AbSTRACT

Carta aos loucos, Carlos Nejar's romance, is an allegoric narrative in which the author, inspired on the tradition of Homero's classical narrative, and making use of the parodist resource creates a new epic, based not on the relating of the already happened, but on the questioning, revealing a post-modern critical conscience. The esayist tries to elevate the ways by which the narrator dares new literary paradigms, recreating the classical mithology towards the binomial Time versus Word and to show how, enriched by the dinamic convenience on prose and poetry, the romance is an apology to "Verb", a thesis shared by the contemporaneous fictionists.

KEY wORDS: Binomial word versus time, modern epics, poetical prose, brazilian literature.

NotA

1. A edição de Carta aos loucos utilizada nessa análise é a de 1998 da Record. As citações de trechos da obra serão, daqui para a frente, seguidas apenas das indicações do número da página. 
REFERÊNCIAS BIBLIOGRÁFICAS

Cortázar, Julio. Valise de Cronópio. São Paulo: Perspectiva, 1974, p. 79.

Heidegger, Martim. Ser e tempo. Parte I. Petrópolis: Vozes, 1988. (Col. Pensamento Humano)

Nejar, Carlos. Cartas aos loucos. Rio de Janeiro: Record, 1988.

Os melhores poemas de Carlos Nejar. Prefácio e Seleção de Léo Gilson Ribeiro. São Paulo: Global, 1988. 